\title{
The Relationship between the Market Value Added of SMEs Listed on AIM Italia and Internal Measures of Value Creation
}

\section{The Role of Corporate Strategic Planning}

\author{
Andrea Quintiliani ${ }^{1}$ \\ ${ }^{1}$ Department of Law and Economic Sciences, Pegaso Telematic University, Naples, Italy \\ Correspondence: Andrea Quintiliani, Department of Law and Economic Sciences, Pegaso Telematic University, \\ Naples, Piazza Trieste e Trento, 48-80132, Italy. Tel: (+39) 081-1913-7500.
}

Received: December 4, 2017

doi:10.5430/ijfr.v9n1p121
Accepted: December 17, 2017 Online Published: December 21, 2017

URL: https://doi.org/10.5430/ijfr.v9n1p121

\begin{abstract}
Objectives - In saying that measurement of financial performance plays an important role in the capital allocation choices, the aim of this study is to test the relationships between Market Value Added (MVA), stockholders value measures and presence of formal strategic plan.

Methodology - The study is among descriptive and correlational researches and using panel data methodology on sample of SMEs listed in AIM Italia. The time under study was from 2010 to 2015. In addition, the hypotheses of the research have been tested using Rahavard Novin software for data collection and SPSS 20.0 for data analysis.

Findings - The results indicate that Refined Economic Value Added (REVA) has more correlation with Market Value Added (MVA) than Economic Value Added (EVA); in addition, the results obtained using panel data methodology shows that the use of strategic plans influences the relationship between value performance measures and MVA.

Research limits - Data used for this study need to be subjected to more statistical tests in order to establish a more robust validity and reliability. It is necessary to acquire further strengthened data and assume a variety of conditional situations. It is expected that subsequent studies can use larger samples and diversified by sector, a broader geographic base and a multi-faceted analyses.

Practical implications - This work offer necessary evidences in order to help capital market participants to make rational decision in investment process.

Originality of the study - The originality of this study is the correlation between MVA, financial measures and use of strategic planning for value management.
\end{abstract}

Keywords: EVA, REVA, MVA, strategic planning

\section{Introduction}

Creating shareholder value is the key to success in today's marketplace. Long since CFOs are committed to measuring, monitoring and managing business value drivers. Studies devoted to shareholders value analysis have suggested several measures. Some of financial measures for stockholders wealth evaluation are: Refined Economic Value Added (REVA), Economic Value Added (EVA), Total Shareholder Return (TSR), Stock Value (SV), Price Earning (PE), Price/Book Value (PBV), Earnings Per Share (EPS), FCFE Growth Rate (FCFEGR), Dividend Per Share (DPS), Residual Income (RI), Residual Operating Income (ReOI), Net Operating Assets (NOA), Profit Margin (PM), Investment Turnover (IT).

Several researches have been conducted internationally consistent with the view that REVA has most correlation with market value than EVA. The most important purpose of the present research is to make clear the theoretical indices of value creation, test these indices and offer necessary evidences in order to help capital market participants to make rational decision in investment process.

In this research, we test information content of aforementioned measures in AIM Italia. Then, to obtain the most suitable internal measure as a measure of MVA, we look for the measures that have the most relationship with 
Market Value Added (MVA).

MVA represent the value added to the particular share over its book value. MVA informs how much value a shareholders has added to this wealth, which he has invested in the share. Accordingly, a company with an objective of enhancing the shareholder's wealth should attempt to capitalize on its MVA.

Findings show that REVA has more correlation with Market Value Added (MVA) than EVA during 2010-2015.

Without prejudice to the aforementioned considerations, we believe that a company increases its value if driven by a growth strategy whose guidelines are included in the strategic plan.

As stated Rappaport (1981): «A principal objective of corporate strategic planning is to create value for shareholders. By focusing systematically on strategic decision-making, such planning helps management allocate corporate resources to their most productive and profitable use. It is commonly assumed that the market value of the company's shares will increase as the plan materializes, thus creating value for shareholders».

The correlation between strategic plan and business value is even more evident if we consider studies on Value Based Management (VBM). As evidenced by Arnold (2005): «Value-based management is a managerial approach in which the primary purpose is long-term shareholder wealth maximization. The objective of a firm, its systems, strategy, processes, analytical techniques, performance measurements and culture have as their guiding objective shareholder wealth maximization».

Some studies show that MVA is the core of a vast system (known as Value Based Management) that includes various management processes, from strategic planning to the incentive of resources, able to effectively contribute to create value over time (Ryan \& Trahan, 1999; Ittner \& Larker, 2001; Malmi \& Ikäheimo, 2003; Lueg \& Schäffer, 2010; Dekker et al., 2012; Burkert \& Lueg, 2013; Elgharbawy \& Abdel-Kader, 2013). Other studies conducted on SMEs show that their loss of value is closely linked to the lack of strategic planning systems (Garengo et al., 2005; Cocca \& Alberti, 2010).

Furthermore, some meta-analysis studies show a positive relationship between strategic planning and financial performance; among these we may mention the studies conducted by: Boyd (1991), Capon et al. (1987, 1990, 1994).

Our work highlights that use of strategic plans influences the relationship between value performance measures and MVA during 2010-2015.

The remainder of the work is organized as follows. Section 2 explains literature reviews. Section 3 explains our hypotheses and present the model. The results and conclusions are discussed in Sections 4 and 5.

\section{Theoretical Background}

Over time different schools of thought have formed on the correlations existing between MVA and theoretical measures of value creation.

Stewart's research $(1990,1991)$ found really high values of $R^{2}(97 \%)$ between the values and changes in values, of EVA and MVA of companies. One important side note is that these correlations were only this high for companies with a positive value of EVA, for companies with a low, or negative EVA, the correlation was not high at all and could even be negative. According to Stewart this was due to the fact that the MVA always reflects the value of the assets of the company, even if the company has negative returns.

Dodd and Chen's studies (1996) focused on the correlation analysis between Stock Market Returns (SMR) and Economic Value Added (EVA), Return On Assets (ROA), Return On Equity (ROE), Residual Income (RI) and Earnings Per Share (EPS). Their empirical analysis on a sample of 566 US companies showed that ROA, in comparison with other measures, shows the greatest correlation $\left(\mathrm{R}^{2}=24.5 \%\right)$. Follow other measures: EVA 20.2 per cent, RI 19.4 per cent and between 5 per cent to 7 per cent for ROE and EPS.

Grant (1996) states that EVA is strongly linked to MVA; such a link is justified by company's residual return on capital.

Bacidore et al. (1997) investigated the relationships between traditional and new performance evaluation measures and MVA. Their results show that the ability of REVA in stock value prediction is more than other measures.

Ittner and Larcker (1998) shows that level of Economic Profit (EP) explain about 31 per cent of the level of MVA; the authors add that correlation level of EP is not very different from the other measures investigated.

Fernandez (2001) studied the relationship between MVA and shareholders value creation. In particular, the author analyzes 582 US companies using data provided by Stern Stewart. For each of the 582 companies, we have 
calculated the 10-year correlation between the increase in the MVA each year and each year's EVA, NOPAT (Net Operating Profit After Taxes), WACC (Weighted Average Cost of Capital). He observed that one cannot introduce EVA as the best performance index and a representative of MVA.

Sandoval (2002) in an empirical study for Chilean companies examined a sample of 62 Chilean companies over the period 1994-1999 using quarterly data. This sample comprises the most traded and representative industrial companies on the Chilean stock market. The study shows evidence about whether EVA dominates REVA.

Swain et al. (2002) in a study of Indian pharmaceutical industry shows that EVA, NOPAT and sales outperform other financial and economic measures in predicting MVA in most of the companies.

Worthington and West (2004) compared the relationships between MVA and traditional performance evaluation measures with stock return. Their results show that accounting income and stock return still has the most relationship.

Singh (2005) in a study of Indian banking listed on the Bombay stock Exchange shows that over 80 per cent of the banks not reach sufficient margins to cover cost of capital. The author points out the statistical significance of the relationship between EVA and MVA and adds that some finer models, such as industry-specific models, may provide additional insights.

Ferguson et al. (2005) studied the relationships between EVA and other performance evaluation measures in improving stock performance during the period of 1983 to 1998 in the Stern Stewart companies. The study shows that EVA and MVA have the most relationship compared to other measures.

Hejazi and Hosseini (2006) studied about the issue that: «Which one of measures (EVA or accounting measures) has most correlation with MVA?». Their results indicate EVA and MVA have more correlation than other measures.

Seoki and Woo (2009) explored the relationships between EVA, MVA and REVA in the U.S. Their results point out that REVA and MVA has the most relationship compared to other measures.

Kangarlouei et al. (2012), in a study of companies listed in Tehran Stock Exchange (TSE) conclude that REVA and MVA have the most positive relationship in TSE and it determinates 27.5 per cent of MVA.

Asadi et al. (2013) shows that the information content of EVA has no priority in explaining the changes in MVA.

\section{Hypothesis, Data and Empirical Model}

The aim of this study is to test the relationships between research variables. Our quantitative research approach is descriptive and correlational.

The research data consists of companies listed on AIM Italia (the market of Borsa Italiana devoted to the Italian small and medium enterprises, which wish to invest in their growth) during the period of 2010 to 2015.

Statistical sampling is conducted with systematic elimination method. The sampled SMEs must meet the following criteria: i) presence of homogeneous data over the past five years; ii) availability of useful data to test research hypotheses.

As a result of these conditions, a sample of 75 firms (of which 50 have presented strategic plans and numerically quantified targets, and others 25 not) was obtained. Table 1 shows the number of firms object of investigation.

Table 1. Structure of the sample

\begin{tabular}{ll}
\hline Presence of strategic plan & SMEs listed on AIM Italia \\
\hline Yes & 50 \\
No & 25 \\
Total & 75 \\
\hline
\end{tabular}

Financial statement and notes issued by AIM Italia were used as a research tool. We used Rahavard Novin software for data collection and SPSS 20.0 for data analysis.

Our analysis model formulates Market Value Added (MAV) as a result of traditional and non-traditional financial measures:

- Refined Economic Value Added (REVA);

- Economic Value Added (EVA); 
- Total Shareholder Return $($ TSR $)=($ Capital gains + Current income $) \div$ Initial stock price. We refers to the summation of dividend received during the year and difference between the ending price of the stock and the beginning price of the stock, divided by the beginning price of the stock;

- Stock Value $(\mathrm{SV})=\mathrm{D} \div \mathrm{WACC}$ - g;

- Price Earning $(\mathrm{PE})=\mathrm{P} \div \mathrm{E}$. The share price at the end of the fiscal year was divided by the company's diluted EPS for PE. PE shows the amount of investment in common stock costs per euro of earnings;

- Price/Book Value $(\mathrm{PBV})=\mathrm{P} \div \mathrm{BV}$. The PBV ratio is the market price per share divided by the book value per share. The market price per share is simply the stock price. The book value per share is a firm's assets minus its liabilities, divided by the total number of shares;

- Earnings Per Share $($ EPS $)=($ Net income - Dividends on preferred stock $) \div$ Average outstanding shares. We used the diluted EPS reported in the company's financial statements as the EPS. Diluted EPS is the ratio of adjusted income available for ordinary shares (reflecting conversion of diluted securities) to the weighted average number of ordinary and potential ordinary shares outstanding;

- FCFE Growth Rate $($ FCFEGR) $=$ Retention rate $\times$ ROE. Measures growth in income from both operating and cash assets. In terms of fundamentals, it is the product of the retention ratio and the return on equity. The use of the retention ratio in this equation implies that whatever is not paid out as dividends is reinvested back into the firm (Damodaran, 2008);

- Dividend Per Share $($ DPS $)=$ Total dividends paid out to shareholders $\div$ Number of shares outstanding. Is the amount of dividends that the shareholders receive on a per-share basis. It is calculated using the total dividends paid out to shareholders over one fiscal year and the number of shares outstanding;

- Residual Income (RI) = NOPAT - Required profit. Is the NOPAT minus the profit required to cover the cost of financing;

- Residual Operating Income $($ ReOI $)=$ NOPAT $-($ WACC $\times$ Net Operating Assets $)$;

- Net Operating Assets $(\mathrm{NOA})=$ Total Assets - Operating Liabilities;

- Profit Margin $(\mathrm{PM})=$ NOPAT $\div$ Sales;

- Investment Turnover $(\mathrm{IT})=$ Sales $\div$ Investment capital

With MVA as the dependent variable and REVA, EVA, TSR, SV, PE, PBV, EPS, FCFEGR, DPS, RI, ReOI, NOA, $\mathrm{PM}$, and IT as the independent variables, the following models are built (1):

$$
\begin{aligned}
M V A=\alpha+\beta_{1} R E V A+\beta_{2} E V A+\beta_{3} T S R & +\beta_{4} S V+\beta_{5} P E+\beta_{6} P B V+\beta_{7} E P S+\beta_{8} F C F E G R+\beta_{9} D P S+\beta_{10} R I+\beta_{11} R e O I \\
& +\beta_{12} N O A+\beta_{13} P M+\beta_{14} I T+e_{i} .
\end{aligned}
$$

As financial management practices, standardized MVA is calculated by dividing the change in MVA by the adjusted equity value at the beginning of the year (2):

Standardized MVA $=$ Change in MVA for the Year $\div$ Adjusted Equity at Beginning of Year.

REVA is a refined value based on EVA. When researching enterprise value, we should consider more on an enterprise's market value instead of its book value. EVA, reflecting an enterprise's future value through its book value, will possibly neglect some subtle factors difficult to identify in the market. REVA replaces the book value in EVA with the market value (3):

$$
\text { Refined Economic Value Added }(\text { REVA })=\text { NOPAT }- \text { WACC }\left(M V_{t-1}\right) \text {. }
$$

Where, NOPAT is the operating profits after tax at end of period; WACC is the Weighted Average Cost of Capital and $\mathrm{MV}_{\mathrm{t}-1}$ is the market value of equity plus the book value of total corporate liabilities after subtracting current interest free liabilities (all of which are related to the period $\mathrm{t}-1$ ).

Standardized REVA is calculated by dividing the change in REVA by the adjusted equity value at the beginning of the year (4):

Standardized REVA $=$ Change in REVA for the Year $\div$ Adjusted Equity at Beginning of Year.

Economic Value Added (EVA) refers to the residual income that is obtained after deducting costs of capital by net operating profit after-tax (5):

$$
E V A=N O P A T-W A C C \times(N A) .
$$


Where, NOPAT is the reported operating profit plus any increase in doubtful receivables reserves, evaluation reserves based on the last incoming first issued; amortization of goodwill, net amounts invested as R\&D costs, and operating profits (including return on investment) after subtracting taxes on cash activities, WACC is the Weighted Average of the Cost of Capital, and NA is Net Assets (book value of net assets at the beginning of the period).

Standardized EVA is calculated by dividing the change in EVA by the adjusted equity value at the beginning of the year (6):

$$
\text { Standardized EVA = Change in EVA for the Year } \div \text { Adjusted Equity at Beginning of Year. }
$$

In the light of our considerations, we formulate four research hypotheses:

- $\mathrm{RH}_{1}$ - There is a relationship between REVA and MVA in AIM Italia.

- $\mathrm{RH}_{2}$ - There is a relationship between EVA and financial performance measures (e.g., TSR, SV, PI, PBV, EPS, FCFEGR, DPS, RI, ReOI, NOA, PM, and IT) with MVA in AIM Italia.

- $\mathrm{RH}_{3}$ - Compared to other financial performance evaluation measures, REVA and MVA have the most correlation in AIM Italia.

- $\mathrm{RH}_{4}$ - The use of strategic plans influences the relationship between value performance measures and MVA.

\section{Findings}

Since the normality of dependent variable (MVA) leads to the normality of the model, the normality of dependent variable should be controlled before regressing the model.

To test hypothesis Kolmogorov-Smirnov test is conducted. The Kolmogorov-Smirnov test (KS-test) tries to determine if two datasets differ significantly. The KS-test has the advantage of making no assumption about the distribution of data.

Therefore, null and alternative hypotheses are:

- $\mathrm{H}_{0}$ - the data (MVA) is normally distributed;

- $\mathrm{H}_{\mathrm{A}}$ - the data (MVA) is not normally distributed.

The hypothesis regarding the distributional form is rejected at the chosen significance level (p) if the test statistic is greater than the critical value. The fixed values of $\mathrm{p}$ are generally used to evaluate the null hypothesis $\left(\mathrm{H}_{0}\right)$ at various significance levels. A value of 0.050 is typically used for most applications.

As can be in table 2, all the coefficients are statistically significant.

Table 2. KS-test for MVA

\begin{tabular}{lllllllc}
\hline N.obs & Mean & S.D. & $\begin{array}{l}\text { Absolute } \\
\text { value of the } \\
\text { most S.D. }\end{array}$ & $\begin{array}{l}\text { Most } \\
\text { positive } \\
\text { deviation }\end{array}$ & $\begin{array}{l}\text { Most } \\
\text { negative } \\
\text { deviation }\end{array}$ & KS-test & p-value \\
\hline 520 & 0.678082 & 0.85818 & 0.056 & 0.056 & -0.046 & 1.109 & 0.094 \\
\hline
\end{tabular}

Source: our elaboration on "AIM Italia" data

According to the Table 2, significance level for MVA is more than 5 percent $(\mathrm{p}>0.050)$ so null hypothesis $\left(\mathrm{H}_{0}\right)$ showing the normality of dependent variable is accepted.

In order to establish if REVA and MVA are related $\left(\mathrm{RH}_{1}\right)$, we did Pearson's chi-squared test and check the p-values.

Like all statistical tests, chi-squared test assumes a null hypothesis and an alternate hypothesis. The general practice is, if the p-value that comes out in the result is less than a pre-determined significance level, which is 0.050 usually, then we reject the null hypothesis:

- $\mathrm{H}_{0}(\mathrm{p}>0.050)$, there is not a significant relationship between REVA and MVA in AIM Italia (the two variables are independent);

- $\mathrm{H}_{\mathrm{A}}(\mathrm{p}<0.050)$, there is a significant relationship between REVA and MVA in AIM Italia (the two variables are related).

Table 3 highlights the main results of testing data for the first hypothesis.

The significant relationship between REVA and MVA is indicated by beta coefficients $(\beta=+0.876 ; \mathrm{p}<0.050$; adjusted $\mathrm{R}^{2}=0.399$ ). In addition, the number of Durbin-Watson Test is 1.998 , which shows that there is not auto correlation problem. With respect to significance level and the number of $\mathrm{F}$ and $\mathrm{T}$ statistic, $\mathrm{H}_{0}$ hypothesis is rejected. Thus, the study fully supports the first research hypothesis $\left(\mathrm{RH}_{1}\right)$. These findings indicate that there is a significant relationship between the Refined Economic Value Added and the Market Value Added which is in line with the results of the study done by Seoki and Woo (2009). 
Table 3. Estimation results $\left(\mathrm{RH}_{1}\right)$

\begin{tabular}{|c|c|c|c|c|c|c|c|c|c|c|}
\hline Variable & $\begin{array}{l}\text { Pearson } \\
\text { correlation } \\
\text { coefficient }\end{array}$ & $\mathrm{R}^{2}$ & Adj $R^{2}$ & $\begin{array}{l}\text { Durbin } \\
\text { Watson } \\
\text { test }\end{array}$ & $\begin{array}{l}\mathrm{F} \\
\text { Statistic }\end{array}$ & $\begin{array}{l}\mathrm{T} \\
\text { Statistic }\end{array}$ & $\begin{array}{l}\text { n. } \\
\text { obs }\end{array}$ & $\alpha$ & $ß$ & $\mathrm{p}$-value \\
\hline $\begin{array}{l}\text { Statistical } \\
\text { relationship } \\
\text { between } \\
\text { REVA and } \\
\text { MVA }\end{array}$ & 0.618 & 0.415 & 0.399 & 1.998 & 110.290 & 15.210 & 520 & $\begin{array}{l}0.28 \\
9\end{array}$ & 0.876 & 0.005 \\
\hline
\end{tabular}

Source: our elaboration on "AIM Italia" data

Competing hypothesis $2\left(\mathrm{RH}_{2}\right)$, argues that there is a relationship between EVA and financial performance measures (e.g. TSR, SV, PE, PBV, EPS, CFEGR, DPS, RI, ReOI, NOA, PM, and IT) with MVA in AIM Italia. The descriptive statistics for the second hypothesis are reported in table 4.

Table 4. Estimation results $\left(\mathrm{RH}_{2}\right)$

\begin{tabular}{|c|c|c|c|c|c|c|c|c|c|c|}
\hline Variable & $\begin{array}{l}\text { Pearson } \\
\text { correlatio } \\
\mathrm{n} \\
\text { coefficie } \\
\mathrm{nt}\end{array}$ & $\mathrm{R}^{2}$ & $\operatorname{Adj} R^{2}$ & $\begin{array}{l}\text { Durbi } \\
\mathrm{n} \\
\text { Watso } \\
\mathrm{n} \text { test }\end{array}$ & $\begin{array}{l}\text { F } \\
\text { Statisti } \\
\mathrm{c}\end{array}$ & $\begin{array}{l}\mathrm{T} \\
\text { Statisti } \\
\mathrm{c}\end{array}$ & $\begin{array}{l}\text { N. } \\
\text { obs }\end{array}$ & $\beta$ & $\begin{array}{l}\text { p-valu } \\
\text { e }\end{array}$ & $\begin{array}{l}\mathrm{H}_{0} \\
\text { or } \\
\mathrm{H}_{\mathrm{A}}\end{array}$ \\
\hline $\begin{array}{l}\text { Statistical RS } \\
\text { (EVA and MVA) }\end{array}$ & 0.509 & 0.125 & 0.122 & 1.839 & 91.602 & 10.711 & 520 & 0.711 & 0.006 & $\mathrm{H}_{\mathrm{A}}$ \\
\hline $\begin{array}{l}\text { Statistical RS } \\
\text { (TSR and MVA) }\end{array}$ & 0.044 & 0.018 & 0.016 & 1.689 & 0.421 & 0.628 & 520 & 0.009 & 0.101 & $\mathrm{H}_{0}$ \\
\hline $\begin{array}{l}\text { Statistical RS } \\
\text { (SV and MVA) }\end{array}$ & 0.039 & 0.015 & 0.014 & 1.587 & 0.329 & 0.558 & 520 & 0.007 & 0.118 & $\mathrm{H}_{0}$ \\
\hline $\begin{array}{l}\text { Statistical RS } \\
\text { (PE and MVA) }\end{array}$ & 0.027 & 0.014 & 0.013 & 1.389 & 0.298 & 0.498 & 520 & 0.004 & 0.187 & $\mathrm{H}_{0}$ \\
\hline $\begin{array}{l}\text { Statistical RS } \\
\text { (PBV and MVA) }\end{array}$ & 0.056 & 0.009 & 0.007 & 1.401 & 0.587 & 0.642 & 520 & 0.012 & 0.100 & $\mathrm{H}_{0}$ \\
\hline $\begin{array}{l}\text { Statistical RS } \\
\text { (EPS and MVA) }\end{array}$ & 0.031 & 0.009 & 0.006 & 1.409 & 0.301 & 0.500 & 520 & 0.006 & 0.189 & $\mathrm{H}_{0}$ \\
\hline $\begin{array}{l}\text { Statistical RS } \\
\text { (CFEGR and } \\
\text { MVA) }\end{array}$ & 0.401 & 0.104 & 0.101 & 1.820 & 88.602 & 10.006 & 520 & 0.708 & 0.007 & $\mathrm{H}_{\mathrm{A}}$ \\
\hline $\begin{array}{l}\text { Statistical RS } \\
\text { (DPS and MVA) }\end{array}$ & 0.368 & 0.102 & 0.100 & 1.755 & 78.871 & 9.589 & 520 & 0.655 & 0.008 & $\mathrm{H}_{\mathrm{A}}$ \\
\hline $\begin{array}{l}\text { Statistical RS } \\
\text { (RI and MVA) }\end{array}$ & 0.320 & 0.099 & 0.097 & 1.700 & 69.896 & 8.687 & 520 & 0.612 & 0.009 & $\mathrm{H}_{\mathrm{A}}$ \\
\hline $\begin{array}{l}\text { Statistical RS } \\
\text { (ReOI and } \\
\text { MVA) }\end{array}$ & 0.290 & 0.087 & 0.085 & 1.698 & 61.220 & 8.458 & 520 & 0.578 & 0.011 & $\mathrm{H}_{\mathrm{A}}$ \\
\hline $\begin{array}{l}\text { Statistical RS } \\
\text { (NOA and MVA) }\end{array}$ & 0.285 & 0.079 & 0.076 & 1.690 & 58.999 & 7.998 & 520 & 0.555 & 0.014 & $\mathrm{H}_{\mathrm{A}}$ \\
\hline $\begin{array}{l}\text { Statistical RS } \\
\text { (PM and MVA) }\end{array}$ & 0.274 & 0.077 & 0.075 & 1.690 & 51.001 & 7.511 & 520 & 0.425 & 0.017 & $\mathrm{H}_{\mathrm{A}}$ \\
\hline $\begin{array}{l}\text { Statistical RS (IT } \\
\text { and MVA) }\end{array}$ & 0.224 & 0.070 & 0.068 & 1.685 & 50.158 & 6.008 & 520 & 0.398 & 0.018 & $\mathrm{H}_{\mathrm{A}}$ \\
\hline
\end{tabular}

Source: our elaboration on "AIM Italia" data

The empirical evidence shows that some variables (EVA, CFEGR, DPS, RI, ReOI, NOA, PM, and IT) are related to MVA whereas others (TSR, SV, PE, PBV, EPS) are independent and assumes null hypothesis $\left(\mathrm{H}_{0}\right)$. As a result, MVA and all the variables in the second hypothesis other than TSR, SV, PE, PBV, and EPS have relationships.

With reference third hypothesis $\left(\mathrm{RH}_{3}\right)$, we can say that REVA and MVA, compared to other indices, are more related. In effect, the data showed that the high of adjusted $\mathrm{R}$ square is 0.399 . It shows that the independent variable (REVA) in this study is able to explain 39.9\% variation in the MVA. This statistical evidence confirms our third hypothesis. The results of testing correspond to the findings observed by Bacidore et al. (1997), Fernandez (2001), Seoki and 
Woo (2009). On the other hand, this finding is contrary to the results of the study done by Sandoval (2002), Swain et al. (2002).

After testing relationships between dependent and independent variables, we regress the model for single independent variable. Here we use multiple regressions to show the effects on the dependent variable. The accepted hypotheses are shown in table 5.

Table 5. Multiple regression (RH3)

\begin{tabular}{llllll}
\hline $\begin{array}{l}\text { Accepted } \\
\text { Hypothesis }\end{array}$ & Adj $\mathrm{R}^{2}$ & Regression Model & p-value & $\begin{array}{l}\text { Independent } \\
\text { Variable }\end{array}$ & $\begin{array}{l}\text { Dependent } \\
\text { Variable }\end{array}$ \\
\hline $\mathrm{H}_{\mathrm{A}}$ & 0.399 & $\mathrm{y}=0.289+0.876 \mathrm{x}+\mathrm{e}_{\mathrm{i}}$ & 0.005 & REVA & MVA \\
$\mathrm{H}_{\mathrm{A}}$ & 0.122 & $\mathrm{y}=0.301+0.711 \mathrm{x}+\mathrm{e}_{\mathrm{i}}$ & 0.006 & EVA & MVA \\
$\mathrm{H}_{0}$ & 0.016 & $\mathrm{y}=0.456+0.009 \mathrm{x}+\mathrm{e}_{\mathrm{i}}$ & 0.101 & TSR & MVA \\
$\mathrm{H}_{0}$ & 0.014 & $\mathrm{y}=0.401+0.007 \mathrm{x}+\mathrm{e}_{\mathrm{i}}$ & 0.118 & $\mathrm{SV}$ & MVA \\
$\mathrm{H}_{0}$ & 0.013 & $\mathrm{y}=0.398+0.004 \mathrm{x}+\mathrm{e}_{\mathrm{i}}$ & 0.187 & PE & MVA \\
$\mathrm{H}_{0}$ & 0.007 & $\mathrm{y}=0.501+0.012 \mathrm{x}+\mathrm{e}_{\mathrm{i}}$ & 0.100 & PBV & MVA \\
$\mathrm{H}_{0}$ & 0.006 & $\mathrm{y}=0.306+0.006 \mathrm{x}+\mathrm{e}_{\mathrm{i}}$ & 0.189 & EPS & MVA \\
$\mathrm{H}_{\mathrm{A}}$ & 0.101 & $\mathrm{y}=0.346+0.708 \mathrm{x}+\mathrm{e}_{\mathrm{i}}$ & 0.007 & CFEGR & MVA \\
$\mathrm{H}_{\mathrm{A}}$ & 0.100 & $\mathrm{y}=0.277+0.655 \mathrm{x}+\mathrm{e}_{\mathrm{i}}$ & 0.008 & DPS & MVA \\
$\mathrm{H}_{\mathrm{A}}$ & 0.097 & $\mathrm{y}=0.201+0.612 \mathrm{x}+\mathrm{e}_{\mathrm{i}}$ & 0.009 & RI & MVA \\
$\mathrm{H}_{\mathrm{A}}$ & 0.085 & $\mathrm{y}=0.222+0.578 \mathrm{x}+\mathrm{e}_{\mathrm{i}}$ & 0.011 & ReOI & MVA \\
$\mathrm{H}_{\mathrm{A}}$ & 0.076 & $\mathrm{y}=0.201+0.555 \mathrm{x}+\mathrm{e}_{\mathrm{i}}$ & 0.014 & NOA & MVA \\
$\mathrm{H}_{\mathrm{A}}$ & 0.075 & $\mathrm{y}=0.301+0.425 \mathrm{x}+\mathrm{e}_{\mathrm{i}}$ & 0.017 & PM & MVA \\
$\mathrm{H}_{\mathrm{A}}$ & 0.068 & $\mathrm{y}=0.299+0.398 \mathrm{x}+\mathrm{e}_{\mathrm{i}}$ & 0.018 & IT & MVA \\
\hline
\end{tabular}

Source: our elaboration on "AIM Italia" data

The descriptive statistics, correlation and multiple regression analysis has been performed using SPSS 20.0 version through ENTER (Tab. 6).

Based on the results of the ANOVA test or F-test in table 6 obtained F count is 34.221 with a significance level of 0.001 . Because the significance level of $0.001<0.050$, it can be stated that the regressed model is accepted.

Table 6. The result of F-Test - ANOVA $\left(\mathrm{RH}_{3}\right)$

\begin{tabular}{lll}
\hline Model & F & p-value \\
\hline Multiple Regression & 34.221 & 0.001 \\
\hline
\end{tabular}

Source: our elaboration on "AIM Italia" data

Table 7 contains the summary statistics through ENTER multiple regressions. Established that p-value is less than 5\% (table 6), regression model accepts null hypotheses for the variables they have level of T-statistic higher than 5\%. It follows that EVA, TSR, SV, PE, PBV, and EPS variables are eliminated from the regression model because they do not have significant relationships with dependent variable (MVA).

However, null hypothesis is not accepted for other variables and these variables must not be omitted from the regression model. Less tolerance indicates that variables' data is low which makes a problem in the regression; but, as it is shown, the tolerance value is acceptable and therefore it does not make a problem in multiple regressions. 
Table 7. Summary of Multiple Regression Applying the Enter Method $\left(\mathrm{RH}_{3}\right)$

\begin{tabular}{lllllllll}
\hline \multicolumn{3}{c}{$\begin{array}{l}\text { Unstandardized } \\
\text { coefficients }\end{array}$} & & & & & \multicolumn{3}{c}{ Collinearity Statistics } \\
Var. & $B$ & Std. & Standardized & T & & & Pariance & \\
& & Error & Coefficients & Statistic & p-value & $\begin{array}{l}\text { Position } \\
\text { Index }\end{array}$ & $\begin{array}{l}\text { Inflation } \\
\text { Factor }\end{array}$ & Tolerance \\
\hline Constant & 0.105 & 0.080 & - & 1.298 & 0.160 & 1.000 & - & - \\
REVA & 0.521 & 0.062 & 0.425 & 4.125 & 0.001 & 2.007 & 1.763 & 0.567 \\
EVA & 0.016 & 0.087 & 0.068 & 0.784 & 0.108 & 2.121 & 1.267 & 0.789 \\
TSR & 0.004 & 0.004 & 0.020 & 0.878 & 0.109 & 2.687 & 1.474 & 0.678 \\
SV & 0.003 & 0.003 & 0.021 & 0.897 & 0.118 & 2.787 & 1.287 & 0.777 \\
PE & 0.002 & 0.002 & 0.018 & 0.901 & 0.187 & 2.874 & 1.912 & 0.523 \\
PBV & 0.008 & 0.008 & 0.028 & 0.871 & 0.100 & 3.001 & 1.506 & 0.664 \\
EPS & 0.003 & 0.003 & 0.023 & 0.945 & 0.189 & 3.487 & 1.386 & 0.721 \\
CFEGR & 0.421 & 0.058 & 0.341 & 3.128 & 0.007 & 2.788 & 1.187 & 0.842 \\
DPS & 0.325 & 0.078 & 0.231 & 3.009 & 0.008 & 2.987 & 1.267 & 0.789 \\
RI & 0.500 & 0.075 & 0.398 & 2.989 & 0.009 & 3.598 & 1.226 & 0.815 \\
ReOI & 0.401 & 0.077 & 0.299 & 2.789 & 0.011 & 4.878 & 1.305 & 0.766 \\
NOA & 0.420 & 0.054 & 0.301 & 2.128 & 0.014 & 4.999 & 1.287 & 0.777 \\
PM & 0.376 & 0.048 & 0.294 & 2.001 & 0.017 & 5.001 & 1.669 & 0.599 \\
IT & 0.298 & 0.037 & 0.201 & 2.879 & 0.018 & 5.215 & 1.663 & 0.601 \\
\hline
\end{tabular}

Source: our elaboration on "AIM Italia” data

Based on the evidence presented so far, the multiple regression model is shown in the formula (7):

$$
\begin{gathered}
y=0.10+0.521 R E V A+0.421 F C F E G R+0.325 D P S+0.500 R I+0.401 R e O I+0.420 \mathrm{NOA}+0.376 P M+0.298 \\
I T+e_{i} .
\end{gathered}
$$

Table 8 highlights the main results of testing data for the fourth hypothesis. Here, the research variables are tested concerning strategic plan as a control variable.

The statistical results in table 8 show, for SMEs with a strategic plan, the greatest relationship between REVA and

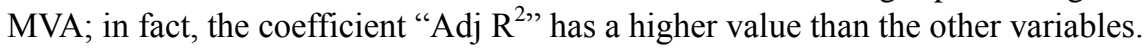

With respect to F and T statistic, null hypothesis is rejected for all the variables other than TSR, SV, PE, PBV, and EPS; moreover, for all variables different from TSR, SV, PE, PBV and EPS, significance of the regression model is accepted.

This means that the use of strategic plans influences the relationship between value performance measures and MVA.

It can be concluded that the presence of the strategic plan affects the relationship between dependent and independent variable so our fourth hypothesis is accepted. 
Table 8. Estimation results $\left(\mathrm{RH}_{4}\right)$

\begin{tabular}{|c|c|c|c|c|c|c|c|c|c|c|c|c|c|c|}
\hline \multirow[b]{2}{*}{ Var. } & \multicolumn{7}{|c|}{ Presence of a Strategic Plan } & \multicolumn{7}{|c|}{ Absence of a Strategic Plan } \\
\hline & $\mathrm{R}^{2}$ & Adj $R^{2}$ & $\begin{array}{l}\text { n. } \\
\text { obs }\end{array}$ & $\begin{array}{l}\text { F } \\
\text { Statisti } \\
\text { c }\end{array}$ & $\begin{array}{l}\mathrm{T} \\
\text { Statist } \\
\text { ic }\end{array}$ & p-value & $\begin{array}{l}\mathrm{H}_{0} \\
\text { or } \\
\mathrm{H}_{\mathrm{A}}\end{array}$ & $\mathrm{R}^{2}$ & $\begin{array}{l}\text { Adj } \\
R^{2}\end{array}$ & $\begin{array}{l}\text { n. } \\
\text { obs }\end{array}$ & $\begin{array}{l}\mathrm{F} \\
\text { Statistic }\end{array}$ & $\begin{array}{l}\mathrm{T} \\
\text { Statisti } \\
\mathrm{c}\end{array}$ & p-value & $\begin{array}{l}\mathrm{H}_{0} \\
\text { or } \\
\mathrm{H}_{\mathrm{A}}\end{array}$ \\
\hline REVA & 0.612 & 0.420 & 347 & 16.456 & 7.120 & 0.001 & $\mathrm{H}_{\mathrm{A}}$ & 0.478 & 0.298 & 173 & 14.256 & 6.189 & 0.001 & $\mathrm{H}_{\mathrm{A}}$ \\
\hline EVA & 0.401 & 0.301 & 347 & 12.001 & 5.345 & 0.002 & $\mathrm{H}_{\mathrm{A}}$ & 0.320 & 0.210 & 173 & 10.998 & 4.997 & 0.001 & $\mathrm{H}_{\mathrm{A}}$ \\
\hline TSR & 0.088 & 0.072 & 347 & 1.401 & 1.146 & 0.090 & $\mathrm{H}_{0}$ & 0.062 & 0.022 & 173 & 1.201 & 1.100 & 0.080 & $\mathrm{H}_{0}$ \\
\hline SV & 0.080 & 0.070 & 347 & 1.306 & 1.107 & 0.110 & $\mathrm{H}_{0}$ & 0.058 & 0.012 & 173 & 1.287 & 1.101 & 0.100 & $\mathrm{H}_{0}$ \\
\hline $\mathrm{PE}$ & 0.091 & 0.080 & 347 & 1.198 & 1.012 & 0.098 & $\mathrm{H}_{0}$ & 0.060 & 0.040 & 173 & 1.099 & 1.000 & 0.091 & $\mathrm{H}_{0}$ \\
\hline PBV & 0.073 & 0.068 & 347 & 1.311 & 1.121 & 0.090 & $\mathrm{H}_{0}$ & 0.041 & 0.020 & 173 & 1.216 & 1.107 & 0.088 & $\mathrm{H}_{0}$ \\
\hline EPS & 0.090 & 0.072 & 347 & 1.234 & 1.098 & 0.112 & $\mathrm{H}_{0}$ & 0.075 & 0.066 & 173 & 1.109 & 1.012 & 0.110 & $\mathrm{H}_{0}$ \\
\hline CFEGR & 0.301 & 0.206 & 347 & 8.301 & 3.118 & 0.003 & $\mathrm{H}_{\mathrm{A}}$ & 0.290 & 0.153 & 173 & 7.001 & 2.987 & 0.002 & $\mathrm{H}_{\mathrm{A}}$ \\
\hline DPS & 0.280 & 0.189 & 347 & 7.222 & 3.002 & 0.004 & $\mathrm{H}_{\mathrm{A}}$ & 0.245 & 0.140 & 173 & 6.333 & 2.452 & 0.002 & $\mathrm{H}_{\mathrm{A}}$ \\
\hline RI & 0.228 & 0.174 & 347 & 6.457 & 2.990 & 0.005 & $\mathrm{H}_{\mathrm{A}}$ & 0.201 & 0.137 & 173 & 5.089 & 2.002 & 0.002 & $\mathrm{H}_{\mathrm{A}}$ \\
\hline $\mathrm{ReOI}$ & 0.200 & 0.156 & 347 & 6.001 & 2.798 & 0.011 & $\mathrm{H}_{\mathrm{A}}$ & 0.188 & 0.122 & 173 & 4.999 & 2.098 & 0.011 & $\mathrm{H}_{\mathrm{A}}$ \\
\hline $\mathrm{NOA}$ & 0.194 & 0.139 & 347 & 5.732 & 2.653 & 0.012 & $\mathrm{H}_{\mathrm{A}}$ & 0.174 & 0.110 & 173 & 4.222 & 2.035 & 0.012 & $\mathrm{H}_{\mathrm{A}}$ \\
\hline PM & 0.184 & 0.111 & 347 & 4.897 & 2.620 & 0.014 & $\mathrm{H}_{\mathrm{A}}$ & 0.164 & 0.108 & 173 & 3.129 & 2.030 & 0.012 & $\mathrm{H}_{\mathrm{A}}$ \\
\hline IT & 0.179 & 0.104 & 347 & 4.119 & 2.512 & 0.015 & $\mathrm{H}_{\mathrm{A}}$ & 0.157 & 0.100 & 173 & 3.025 & 2.000 & 0.013 & $\mathrm{H}_{\mathrm{A}}$ \\
\hline
\end{tabular}

Source: our elaboration on "AIM Italia" data

\section{Conclusion and Suggestion Remarks}

In line with research objective, this study asked two research questions: i) which financial indicators are most able to capture the dynamics of the market value of the companies listed in AIM Italia?; ii) the presence of a strategic plan can influence MVA or the ability of the company to create value for its shareholders? These questions led us to formulate four research hypotheses.

The first question aims to provide useful evidence to help investors make correct decisions in the investment process in AIM Italy, while the second question aims to offer useful indications to CEOs and CFOs (of firms listed in AIM Italia) engaged to maximize and protect shareholder value.

In answer to the first question, our study indicates that there is no strong evidence to support scientific literature claim that EVA is superior to traditional performance measures in its association with MVA. We can say that although EVA does measure performance well, REVA is a more appropriate measure. In fact, statistical analysis has highlighted that REVA and MVA, compared to other indices, are more related (Adj $\mathrm{R}^{2}=0.399$ ). The consensus is based on using the market-value of the firm in valuing calculations as opposed to book-value figures. Finally, we can conclude that thesis of Bacidore et al. (1997), Seoki and Woo (2009) and Kangarlouei et al. (2012) are proved in AIM Italia.

As regards the second question, in line with VBM management approaches (Rappaport, 1981; Arnold, 2005), the presence of a corporate strategic planning allows managers to focus on value creation rather than on short-sighted accounting numbers. This shift in focus should ultimately enhance the Market Value Added of the SMEs. The study results indicate that REVA with 0.420 adjusted $\mathrm{R}^{2}$ have the most positive and liner relationships with MVA. Findings of our study converge, in part, with the empirical studies of Boyd (1991), Capon et al. $(1987,1990,1994)$ who see strategic planning as instrument to improve performance.

Considering the results of the study, following remarks are suggested:

- REVA is suitable indicator to support decision-making processes as it able to give significant information in medium to long-term planning.

- Capital market participants must necessarily see in REVA the most suitable indicator for evaluating performance 
of value-oriented firms.

- Managers must utilize REVA along with other measure to evaluate firms' financial performance and to make the sound decisions about investments.

- Decision-making process must be supported by a strategic plan because it has a significant effect on the relationships between financial performance measures and MVA.

- The research variables strong related to MVA are concrete and directly manageable by managers and can be used when establishing strategic planning for value management.

- All the findings in this research can be used for supporting or even completing other studies with similar or same concept, after necessary adjustments have been made.

\section{References}

Arnold, G. (2005). The handbook of corporate finance. A business companion to financial markets, decisions and techniques. Edinburgh, UK: Pearson Education Limited.

Asadi, A. R., Zendeh-del, A., \& Kianinezhad, A. (2013). Relation of Information Content of Economic Value Added and Traditional Measures with Market Value Added. Accounting and Auditing Review, 20(2), 1-18.

Bacidore, J. M., Boquist, J. A., Milbourn, T. T., \& Thakor, A. V. (1997). The search for the best financial performance measure. Financial Analysts Journal, 53(3), 11-20. https://doi.org/10.2469/faj.v53.n3.2081

Boyd, B. K. (1991). Strategic planning and financial performance: a meta-analytic review. Journal of Management Studies, 28(4), 353-374. https://doi.org/10.1111/j.1467-6486.1991.tb00286.x

Burkert, M., \& Lueg, R. (2013). Differences in the sophistication of Value-based Management - The role of top executives. Management Accounting Research, 24(1), 3-22. https://doi.org/10.1016/j.mar.2012.10.001

Capon, N., Farley, J. U., \& Hoenig, S. (1990). Determinants of Financial Performance: A Meta-Analysis. Management Science, 36(10), 1143-1159. https://doi.org/10.1287/mnsc.36.10.1143

Capon, N., Farley, J. U., \& Hulbert J. M. (1994). Strategic planning and financial performance: more evidence. Journal of Management Studies, 31(1), 105-110. https://doi.org/10.1111/j.1467-6486.1994.tb00335.x

Capon, N., Farley, J. U., \& Hulbert, J. M. (1987). Corporate Strategic Planning. New York, NY: Columbia University Press.

Cocca, P., \& Alberti, M. (2010). A framework to assess performance measurement systems in SMEs. International Journal of Productivity and Performance Management, 59(2), 186-200. https://doi.org/10.1108/17410401011014258

Damodaran, A. (2008). Damodaran on Valuation: Security Analysis for Investment and Corporate Finance. New Jersey, NJ: Wiley Finance.

Dekker, H. C., Groot, T., Schoute, M., \& Wiersma, E. (2012). Determinants of the Use of Value-based Performance Measures for Managerial Performance Evaluation. Journal of Business Finance \& Accounting, 39(9-10), 1214-1239. https://doi.org/10.1111/jbfa.12004

Dodd, J. L., \& Chen, S. (1996). EVA: A New Panacea? Business \& Economic Review, 42(4), 26-28.

Elgharbawy, A., \& Abdel-Kader, M. (2013). Enterprise governance and value-based management: a theoretical contingency framework. Journal of management \& Governance, 17(1), 99-129. https://doi.org/10.1007/s10997-012-9220-y

Ferguson, R., Rentzler, J., \& Yu, S. (2005). Does Economic Value Added (EVA) Improve Stock Performance Profitability? Journal of Applied Finance, 4(2), 101-113. Retrieved from https://papers.ssrn.com/sol3/papers.cfm?abstract_id=2335465

Fernandez, P. (2001). EVA, Economic Profit and Cash Value Added Do Not Measure Shareholder Value Creation. Retrieved from https://papers.ssrn.com/sol3/papers.cfm?abstract_id=270799

Garengo, P., Biazzo, S., \& Bititci, U. S. (2005). Performance Measurement Systems in SMEs: A Review for a Research Agenda. International Journal of Management Reviews, 7(1), 25-47. https://doi.org/10.1111/j.1468-2370.2005.00105.x

Grant, J. L. (1996). Foundations of EVA ${ }^{\mathrm{TM}}$ for Investment Managers. The Journal of Portfolio Management, 23(1), 41-48. https://doi.org/10.3905/jpm.1996.409573

Hejazi, R., \& Hoseini, A. (2006). Comparing the relationship between the market value added and economic value added with accounting standards in the Tehran Stock Exchange. Economic Bulletin, 23, 237-262. 
Ittner, C. D., \& Larcker, D. F. (1998). Innovations in performance measurement: Trends and research implications. Journal of Management Accounting Research, 10, 205-238. Retrieved from https://papers.ssrn.com/sol3/papers.cfm?abstract_id=137278

Ittner, C. D., \& Larker, D. F. (2001). Assessing managerial research in management accounting: a value-based management perspective. Journal of Accounting and Economics, 32(1-3), 349-410. https://doi.org/10.1016/S0165-4101(01)00026-X

Kangarlouei, S. J., Azizi, A., Sarbandi, M., Farahani, M. S., \& Motavassel, M. (2012). The Search for the Best Financial Performance Measure of Companies Listed in Tehran Stock Exchange (TSE). World Applied Sciences Journal, 16(3), 407-414.

Lueg, R., \& Schäffer, U. (2010). Assessing empirical research on value-based management: Guidelines for improved hypothesis testing. Journal für Betriebswirtschaft, 60(1), 1-47. https://doi.org/10.1007/s11301-009-0055-9

Malmi, T., \& Ikäheimo, S. (2003). Value Based Management practices-some evidence from the field. Management Accounting Research, 14(3), 235-254. https://doi.org/10.1016/S1044-5005(03)00047-7

Rappaport, A. (1981, May 01). Selecting Strategies That Create Shareholder Value. Harvard Business Review, 139.

Ryan, H. E., \& Trahan, E. A. (1999). The utilization of Value-Based Management: An empirical analysis. Financial Practice \& Education, 9(1), 46

Sandoval, E. (2002). Financial performance measures and shareholders value creation: An empirical study for Chilean companies. The Journal of Applied Business Research, 17(3), 109-122. https://doi.org/10.19030/jabr.v17i3.2239

Seoki, L., \& Woo, G. K. (2009). EVA, refined EVA, MVA, or traditional performance measures for the hospitality industry? International Journal of Hospitality Management, 28(3), 439-445. https://doi.org/10.1016/j.ijhm.2009.01.004

Singh, P. (2005). EVA in Indian Banking: Better Information content, More Shareholder Value. Abhigyan, 23(3), 40-49.

Stewart, G. B. (1990). The Quest for Value: the EVA management guide. New York, NY: Harper Business.

Stewart, G. B. (1991). The Quest for Value: A Guide for Senior Managers. New York, NY: Harper Business.

Swain, R., Mishra, C., \& Kumar, M. (2002). EVA \& MVA: A Study of the Indian pharmaceutical industry. In N. Swain and C. Mishra (Eds.), Economic value added: Concepts and cases. Hyderabad, India: ICFAI Press.

Worthington, A. C., \& West, T. (2001). The Usefulness of Economic Value-Added (EVA) and its Components in the Australian Context. Accounting, Accountability and Performance, 7(1), 73-90. Retrieved from https://ssrn.com/abstract=2169809 